\title{
IMPACT OF COVID-19 ON ISLAMIC PHYLANTROPHIC
} BEHAVIOR OF LECTURERS

Riyan Pradesyah $^{1}$
IIJSE Universitas Muhammadiyah Sumatera Utara, Medan, Indonesia riyanpradesyah@umsu.ac.id

\author{
Al Bara ${ }^{2}$ \\ Universitas Muhammadiyah Sumatera Utara, Medan, Indonesia \\ albara@umsu.ac.id
}

\begin{abstract}
The spread of the Covid-19 virus in Indonesia has an impact on all sectors, and one sector that is currently experiencing a significant impact is the economic sector. Universitas Muhammadiyah Sumatera Utara (UMSU), is an A-accredited private campus, which now still provides fixed salaries and incentives, there is no reduction even though the spread of covid has an impact on all sectors. Many private campuses in Medan City have reduced the salaries of their employees, and even removed some incentives to reduce the budget used, but not for UMSU which still provides obligations and other incentives. In this case, it means that the welfare of Muhammadiyah University employees is still being considered by the leadership stakeholders, but from the observations made, researchers see a decrease in infaq obtained by LAZISMU Medan City. Therefore, the researchers want to see the relationship between the spread of the Covid-19 virus and the philanthropy embraced by employees of UMSU. The Islamic philanthropy is in form of infaq and alms. The research is descriptive qualitative research, which the results obtained will be described or narrated in accordance with the rules of qualitative research. From the results obtained, that there was a shift in Islamic philanthropy carried out by UMSU employees, this happened only a few months after the outbreak of Covid-19 which spread in the city of Medan.
\end{abstract}

Keywords: Covid-19, Islamic Philanthropy, Infaq, Alms 


\section{INTRODUCTION}

Islam is a religion that prioritizes the problems of its people. All aspects of life are a concern, from giving a child's name to defecate. Islam is very complex, even Syafi'i Antonio mentions in his book that Islam is a way of life. In Islam, the pillars of Islam are known. The pillars of Islam are the essence of Islam itself, beginning with the creed, then prayer, zakah, fasting and ending with Hajj (for those who can afford it) where all of these are obligations that must be carried out by a Muslim.

Poverty is a latent problem that has never been discussed. Currently, poverty does not only include food shortages, but also includes income (economic), education, access to health, and access to information. Various kinds of government efforts have been made to reduce poverty. At the macroeconomic level, the government encourages inclusive economic growth, maintains price stability, and increases the availability of productive fields. In this case, various social economic policies have been adopted by the government, such as food assistance programs (rastra), conditional cash transfers (PKH) and health insurance assistance (BPJS/KIS). With the aim of tackling poverty, it is not necessarily followed by a reduction in the poverty rate. Therefore, poverty is said to be a long-term social economic problem, like a disease that continues to erode people's lives.

In this country, the potential for supporting welfare that cannot be denied is philanthropy. The current philanthropic movement is marked by the existence of various non-governmental organizations that rely on funding from the community for social services, both at the local and international levels. The philanthropy is divided into two typologies; (1) Philanthropy that comes from the tradition of generosity (giving) as taught in religious doctrine. (2) Secular philanthropy that emerged as a response to industrialization which gave birth to a new middle class who cared about the poor. Philanthropy seeks to raise public awareness and involvement to allocate funding in order to contribute to social activism (Hasananuddin \& Ginting, 2021).

There are a number of Islamic organizations growing and developing in Indonesia. Almost all of these religious organizations are engaged in education, da'wah, and social charity. Muhammadiyah is an Islamic movement, proselytizing amar makruf, nahi munkar, and tajdid which is based on the Qur'an and As-Sunnah. It is also often called an organization of Islamic renewal and revival when viewed from the perspective of the 
meaning of tajdid. Deliar Noer called Muhammadiyah as a modern Islamic movement organization. In all the components of the association mentioned above, it is always emphasized that the implementation of the entire program is part of good deeds which are identical with the meaning of philanthropy (Amsari \& Nasution, 2020). One of the Muhammadiyah charities in North Sumatra is Universitas Muhammadiyah Sumatera Utara (UMSU).

UMSU is one of the largest universities in North Sumatra and is the only private university that has an A accreditation in North Sumatra. Not only that, UMSU is also a university that experienced student survival during the Covid-19 outbreak that hit Indonesia. Many private campuses in North Sumatra have decreased students, but not with UMSU which is still experiencing stability in students. UMSU continues to provide appropriate salaries to its employees, even though Indonesia is globally affected by the recession. It means that the welfare of Muhammadiyah university employees is still being considered by leadership stakeholders, but from the observations made, researchers see a decrease in infaq received by mosques and LAZISMU institutions in Medan City. Therefore, the researchers want to see the relationship between the spread of the Covid-19 virus and the philanthropy embraced by employees of UMSU in case of infaq.

\section{REVIEW OF LITERATURE}

Philanthropy comes from the Greek, consisting of philaen which means love and anthropos which means human. Philanthropy is the act of someone who loves fellow human beings and human values, so that they donate their time, money and energy to help others. In fact, throughout human history, the level of their existence in an effort to meet the needs of life as creatures with needs (homo economicus) has never existed at the same level of ability, both because of their physical factors, as well as other factors that are outside of humans. Even in humble societies, natural factors are the main elements and determinants of human survival (Nasution, Irwan, \& Samosir, 2019). Islamic philanthropy is something often done by humans, in helping the community or the surroundings where they carry out their daily activities. In the development of meaning, Islamic philanthropy includes, zakah, waqf, infaq and alms. If there is Islamic Philanthropy, the community can 
help other communities in meeting their needs, improving the economy, and others (Mujiatun, 2018).

The previous studies taken or presented in this study were sourced from research, while those taken or described in the previous study started from the author's name, title, year of publication, the method used, and the results obtained. The previous studies taken from several studies are as follows:

First, Fitri Kurniawati conducted research entitled "The Philosophy of Zakah in Islamic Philanthropy". He conducted research in 2017. The research method used is a descriptive qualitative approach. The results of the research are the philosophy of the obligation to pay zakah is religious belief, equity and justice, productivity, freedom, ethics and fairness. While the philosophy of zakah is as istikhlaf, social solidarity, and brotherhood. From this philosophy, it can be seen the essence of zakah itself, namely as something that is very beneficial for all parties (Kurniawan, 2017).

Second, Ismail conducted a study entitled "Implementation of Philanthropic Behavior in Islamic Religious Education (Case Study at SMP Muhammadiyah Plus Salatiga 2018/2019 Academic Year)". He conducted research in 2020. The research method used is field research with a qualitative approach. Observation, interviews, and documentation are methods that researcher used to collect data. The results of the study are First, the school's efforts to implement philanthropic behavior by deepening religious material, habituation, and controlling from various parties. Second, the forms of philanthropy that occur in schools are divided into two forms, namely; traditional charity philanthropy and social justice philanthropy as community advocates. Third, supporting factors such as; a structured and planned program. While the inhibiting factors such as; lack of sense of responsibility, level of religious awareness, lack of understanding of philanthropy, peers and economic conditions as well as awareness of parents (Ismail, 2020).

Third, Husnatul Mahmudah conducted research entitled "Poverty and Islamic Philanthropy". He conducted research in 2019. The research method used was a qualitative approach. The results of this study are Islamic philanthropy with various aspects aimed at realizing social justice. However, considering that social justice itself has various dimensions, it is impossible if only Islamic philanthropy can handle it. Therefore, at least 
Islamic philanthropy has a strategic role in paving the way for realizing social justice through civil society, including with the aim of law enforcement and policies that encourage social justice. Optimizing the function of zakah and waqf institutions that are driven by the power of civil society should be more touching on the economic aspects of development in the sense that it does not only stop at the provision of basic necessities (Maheasy, 2019).

Fourth, Hafidz Arfandi conducted research entitled "Motives and Strategies of the Muhammadiyah Philanthropy Movement”. He conducted research in 2016. The research method used is a descriptive qualitative approach. The results of the research obtained are that Muhammadiyah is an example of the existence of a community in the context of creating social welfare. In the pluralism welfare system, its presence is very helpful in strengthening social capital in society. Muhammadiyah, which was born from the encouragement of Islamic values, is able to reproduce a welfare service, both in the form of facilities and services for education, health, economics and social as well as in the form of direct compensation and empowerment. The initial motive for the birth of Muhammadiyah emerged as a response to the social conditions of its time and later developed into a tradition within the institution that continues to be reproduced and maintained until now as a movement identity. The presence of Muhammadiyah as a volunteer sector provides three significant influences. First, strengthening the resources of the state in times of crisis and in good economic times in the context of providing social services. Second, maintain the collective solidarity of the community and suppress the dependence of the community on state social services. Third, it becomes a balancing and supporting force when the state intentionally ignores its obligation to provide welfare services to the community, as in the colonial era.

Muhammadiyah's commitment to promote welfare is not counterproductive to the goal of the birth of the state or the welfare state. The role is far different from the conception of several Islamist groups, both at home and abroad, who use the philanthropic movement to undermine the legitimacy of the state. Conceptually, the idea of a third sector service of Muhammadiyah that is inclusive (not just for the group) can be reproduced and introduced as a buffer system to support the welfare state which is experiencing limitations in the midst of a world economy that is not very conducive (Arfandi, 2016). 
Fifth, Zaenal Abidin conducted research entitled "Paradox and SynergySustainability-Completion Philanthropy Movement in Indonesia”. He conducted research in 2016. The research method used is qualitative research. The result of the research is that community development based on the strength of local potential has become a strategic issue in recent years. Local potential is expressed in community self-help activities in various aspects of activities in social life. The form of self-reliance is in the form of participation in the construction of bridges, village roads, meeting buildings, and even social care for others. This reality is part of social cohesion that cannot be underestimated by the government, but later become part of strengthening the role of civil society in Indonesia.

Civil Society can be interpreted as the reality of an organized social life that is voluntary, self-supporting, self-sufficient and free from state pressure. This portrait of the civil society movement in Indonesia is growing rapidly, one of which is the emergence of philanthropic activities and institutions, whether religious or not. Philanthropic practices, either individually, in groups, or corporately, are getting more and more active so that it becomes appropriate for us not to just believe, or to surrender to philanthropic activities without being critical of them (Abidin, 2016).

Sixth, Lak lak Nazhat El Hasanah conducted research entitled "Social Entrepreneurship Development in Higher Education through Social Project Competition". He conducted research in 2018. The research method used is descriptive qualitative while the determination of the sample was done by purposive random sampling method. Data collection uses a combination of approaches that include surveys, observations, field studies, and interviews. The results showed that the implementation of social entrepreneurship development was carried out in the form of a competition with the title Social Project Competition program. The program is expected to create graduates who have business independence as well as social sensitivity and provide a balance of academic abilities, attitudes, and work in the context of community self-development, either as professional, independent, and innovative social entrepreneurs. The competition is intended for students who have an interest in social-based business development. The results of the competition obtained three winners who met the sociopreneur elements, namely Social Value, Civil Society, Innovation, Economic Activity. The winners of the competition are 
community empowerment and economic development of diaper waste processing on the banks of Code River, Mimpi Kita, and SUKAWA (Etawa Goat Milk). The winner of the competition is expected to create a social business that improves people's welfare (Hasanah, 2018).

Seventh, Hasyimsyah Nasution and his colleagues conducted research entitled "Empowerment of Philanthropy in Improving the Welfare of Muhammadiyah Citizens in Indonesia". They conducted research in 2019. The research method used is a qualitative approach. The results of the study that the pattern of motivating philanthropy among Muhammadiyah residents in three PWM Muhammadiyah: East Java, Yogyakarta, and North Sumatra, were quite varied. Even though they are varied, there are basic patterns that are used as patrons from central to regional leaders that have been formulated in the management of Institution of Zakah, Infaq, and Alms Muhammadiyah (LAZISMU). The factors that influence philanthropy are understanding of religion, culture, economic conditions, exemplary leadership, and transparent and accountable management of LAZISMU. In collecting philanthropic funds, there is a difference between Java (East Java and Yogyakarta) and North Sumatra. In North Sumatra, every time a tabligh akbar activity is held which is a study at the Branch, PDM, and PWM levels, it is always followed by fundraising activities through the Charity Movement (GAS). This kind of thing is not found in PWM East Java and Yogyakarta. Apart from Muhammadiyah residents, philanthropic funds are also obtained from the wider community, even from non-Muslims, especially for financing orphanages and natural disasters. Fund management is carried out by modern management by prioritizing transparency and accountability. The distribution of philanthropic funds is intended to support the physical development of business charities in Muhammadiyah such as school/madrasah buildings, mosques, orphanages, and hospitals (Nasution, Irwan, \& Samosir, 2019).

\section{RESEARCH METHOD}

The research is a qualitative descriptive analytical study, because in this study, researchers wanted to see what things happened during the collection of zakah and infaq, during the Covid-19 period. Data collection was carried out through a zakah collection institution in collaboration with UMSU, then interviewed with institutional managers. The 
data taken or the data to be analyzed is data related to what was asked of the informant. Then, it is described or narrated according to need, and then conclusions are drawn.

\section{RESULTS AND DISCUSSION}

Philanthropy is an act of someone in loving fellow human beings and human values, thus donating their time, money and energy to help others. In a simple sense, a philanthropist is said to be someone who can do good deeds with the possessions they have. The term philanthropy this time is associated with Islam, so Islamic philanthropy covers zakah, infaq, waqf, and alms (Sinambela \& Saragih, 2018). These things can help people in economic development and even daily life. In this study, researchers only discussed infaq and alms done by lecturers at UMSU. Researchers took data from LAZIMU in Medan. The reason for choosing to collect data at the institution is because UMSU cooperates with LAZISMU, so that infaq and alms issued by UMSU lecturers will usually be distributed to LAZISMU. The results obtained were that during the entry of the Covid-19 virus into Indonesia, UMSU, followed instructions from the government, to do work from home. It is certainly a challenge for lecturers to teach through applications, there are even some lecturers who try to do learning by calling their students and explaining materials related to the topic of discussion. Since the implementation of Work from Home or what is often abbreviated as WFH, many people have complained about the decline in income, there are even some companies that try to lay off their employees without getting input or turnover, but there are also those who lay off their employees in order to maintain the sustainability of the company, and of course there is also a cut in the salaries of their employees.

In an interview conducted by LAZISMU staff and UMSU permanent lecturers, about raising funds during the spread of the Covid-19 virus in Indonesia in 2020, he explained that there was a decrease in funds obtained, if previously the funds obtained reached tens of millions per month, then when the virus spreads only to get millions of rupiah. This decrease was due to the inactivity of the community, thus causing the collection of funds to decrease. And usually, fundraising is done directly or often referred to as picking up the ball, such as coming directly to the university, by leaving an infaq box in each faculty at UMSU. Furthermore, LAZISMU socializes the collection of infaq and 
alms funds online, like sending via LAZISMU account. It was very effective, because after the socialization, fundraising returned to normal at UMSU, although the increase tends to be slow, it continues to increase.

The same explanation was also presented by the UMSU lecturers, who said that during the spread of the Covid-19 in Indonesia, they carried out or issued infaq and alms in the area where they lived, because there were no tools used for online fundraising carried out by LAZISMU. But when there are leaflets distributed by the faculty, then of course they will return to distribute their infaq and alms funds at LAZISMU. Although the increase tends to be slow, but continues to increase.

The fear or worry still occurred during the first 4 months when the Covid-19 virus spread in Indonesia, especially the city of Medan. The workers and companies laid off their employees, even to the end that many companies laid off their employees, due to the absence of turnover, it was used to reduce company expenses. But there are also companies and institutions that reduce the salaries of their employees, with the consideration that the company or institution is getting a reduced input of funds. This concern continues to grow in the city of Medan, even people withdraw their money in the bank, due to the many news that hit the public, that the bank will also go bankrupt, so many people flocked to withdraw their money in the bank so that inflation occurred in Indonesia. For this reason, there are also many people who try not to issue infaq and alms that they usually spend, or spend infaq and alms in small amounts than usual. It was also described by the UMSU lecturer, who at the time of the outbreak the Covid-19, people are really scared, so they try to manage their finances as well as possible, especially when there is a lot of news about the community released by the company.

The reduction is also in line with the answer from LAZISMU staff, that during the spread of the Covid-19 in Indonesia, especially during the first 4 months, the collection of infaq funds was almost non-existent, even in the first month of distribution, they only received one hundred twenty-five thousand rupiah. But even so, LAZISMU tries to continue educating the public, including lecturers. Besides that, your custom is also promoting young ways to spend infaq and alms during the pandemic (Bara, Pradesyah, \& Ginting, 2019).

From the results of the interviews and discussion above, it can be concluded that there 
is a shift in Islamic philanthropy in UMSU lecturers, where during the pandemic UMSU lecturers did not issue their infaq and alms in zakah institutions in collaboration with UMSU. It's just that they issue infaq and alms in other zakah institutions, or in other places close to their respective residences. This shift occurred only in the place of distribution, but not in the distribution of infaq and alms which are often carried out by UMSU employees. The distribution of infaq is still carried out by UMSU employees, it's just that the distribution is carried out at their respective residences, it is done because during the spread of Covid-19, all the academic community is at home, or working from home,

\section{CONCLUSION}

From the results of the research conducted, it can be concluded that there was a shift in Islamic philanthropy in UMSU Lecturers, where the shift occurred in the first four months when the initial pandemic occurred, or the entry of the Covid-19 into Indonesia. However, the shift is not total, where there are still lecturers who issue infaq and alms in zakah institutions in collaboration with UMSU. However, there are also lecturers who continue to issue their infaq and alms in the area where they live, due to government regulations that require working from home only.

\section{REFERENCES}

Abidin, Z. (2016). Paradoks Dan Sinjutas (Sinergi-Keberlanjutanketuntasan) Gerakan Filantropi Di Indonesia. SHARE: Socil Work Journal, 6(2), 154-272.

Amsari, S., \& Nasution, S. (2020). Benefits Of Productive Zakat In Increasing Mustahik Revenue In Lazismu Center. International Seminar of Islamic Studies. 1, ss. 141150. Medan: Fakutas Agama Islam.

Arfandi, H. (2016). Motif dan Strategi Gerakan Filantropi Muhammadiyah. Muhammadiyah Studies, 127-155.

Bara, A., Pradesyah, R., \& Ginting, N. (2019). Strategi Pengelolaan Zakat Produktif Dalam Pengentasan Kemiskinan (Studi Kasus Lembaga Zakat Muhammadiyah Kota Medan). Misykat al-Anwar Jurnal Kajian Islam dan Masyarakat, 2(2), 186-195.

Hasanah, L. 1. (2018). Pengembangan Kewirausahaan Sosial PadaPerguruan Tinggi Melalui Social Project Competition. Jurnal Studi Pemuda, 7(2), 90-99. 
Hasananuddin, \& Ginting, N. (2021). Building The Philantrophy Spirit Of Young Islam Through Islamic Higher Education. International Seminar of Islamic Studies. 2, ss. 722-726. Medan: Fakultas Agama Islam.

Ismail. (2020). Implementasi Perilaku Filantropi dalam pendidikan Agama Islam(Studi Kasus di SMP Muhammadiyah Plus Salatiga Tahun Pelajaran2018/2019). Repository IAIN Salatiga, 1-73.

Kurniawan, F. (2017). Filosofi Zakat Dalam Filantropi Islam. Adzkiya: Jurnal Hukum dan Ekonomi Syariah, 5(2), 231-254.

Mahmudah, H. (2019). Kemiskinan Dan Filantropi Islam. ESA: Jurnal Ekonomi Syariah, 2(1), 1-21.

Mujiatun, S. (2018). The Constraints Of Management Of Zakat And Its Potentials In Poverty Reduction (Case Study Medan City). Advances in Social Sciences Research Journal, 5(6), 104-109.

Nasution, H., Irwan, \& Samosir, H. E. (2019). Pemberdayaan Filantropi Dalam Meningkatkan Kesejahteraan Warga Muhammadiyah Di Indonesia. Miqot, 43(2), 278-299.

Sinambela, E., \& Saragih, F. (2018). Model Penyaluran Dana Zakat, Infaq Dan Shadaqah Bagi Pengembangan Usaha Kecil Menengah Pada Baznas Sumatera Utara. Kumpulan Penelitian dan Pengabdian Dosen, 1(1), 1-49. 